\title{
Enabling and Impending Factors of NGOs in Karnali Zone, Nepal
}

\author{
Kushendra Bahadur Mahat ${ }^{1}$ \& Prof. Dr. Bihari Binod Pokharel ${ }^{2}$
}

${ }^{1}$ PhD Scholar, Dr. K. N. Modi University, Newai, Rajasthan, India

2 Director, Master of Business Management Program, Nepal Commerce Campus, Tribhuwan University, Minbhawan, Kathmandu, Nepal

\section{Corresponding Author}

Kushendra Bahadur Mahat

Email: kmahat@kirdarc.org

\begin{abstract}
Introduction: Nongovernmental Organizations (NGOs) are one of the major parts of the Civil Society institutions to develop the nation. Government has established the separate social welfare act to register and operate to contribute their efforts as complementary support for addressing the basic development requirements of the community to synergic the joint efforts of the development stakeholders. The study was conducted in Midwestern Development Region of Karnali Zone in Nepal where Social Welfare Council and Donor communities are highly prioritized to mainstream into national development process. Objective: The objective of this research was to identify the enabling and impending factors of NGOs in Karnai Zone, Nepal. Methodology: This study was based on the pragmatism philosophy. The study had done 45 indepth interview and 15 focus group discussion with key informants. Qualitative analysis was done to identify the enabling and impending factors of NGOs. Result: Nine factors find the enabling and 7 points impending in general. In enabling factors are the will power of the NGOs, donors are interested and their priority, structural factors, environmental, ethical, program based, policy and democratic practice in the institution. Similarly, impending factors were geographical factors, weak planning and implementation, dependency mentality, lack of trained human resources, inadequate coordination and socio-economic problem. Conclusion: Impending factors may cause the problem in performances of NGOs so it is necessary to minimize the effect of impending factors by addressing though policy and program.
\end{abstract}

KEYWORDS: Enabling, Impending, Factors, NGOs, Karnali, Nepal

\section{INTRODUCTION}

This study focused to identify the enabling and impending factors of the NonGovernmental Organization in Nepal. The study was undertaken in Karnali Zone of Nepal. In the last few years, there has been a huge concern among the civil societies, government and international development partners about improving the quality of the life of people. Nepal government along with the support of donor countries and multilateral funding agencies has invested huge resources to the implementing development project through NGOs. Many organizations including NGOs have spent a significant amount of resources towards assessing development initiatives through project intervention. The focus of all these investments and efforts is to create the equitable prosperous society but such investment is not always based on the proper assessment of the local needs and expectations.

As the number of NGOs increases, competition for scarce resources also increases (Smillie, 1994, p. 167). Donors will increasingly favor those NGOs that already have strong 
management systems or are in the process of putting them in place (Lenihan, 2006, p. 422). While NGOs clearly compete with each other for public recognition, media attention and private donor support, there is, with a few exceptions, generally little competition - in the true sense of the word - for government funding. Although many governments provide support on a projectby-project basis, most NGOs in most countries have reasonable expectations of continuing support from year to year (Smillie, 1994, p. 168).Increasingly, NGOs are being seen as one type of institution in the 'third sector' of society. The organizations in this sector differentiate themselves from governments and commercial enterprise in that their purposes are driven by values, whereas the primary objectives of the government is to control and regulate, and those of businesses are likely to make profits for the owners (Fowler, 1991, p. 15). It is well accepted that NGOs are significant players in the development field (Lenihan, 2006, p. 422) in all countries. Because of the geographic, need of society or nation, the objective and motives of NGOs are different. They are contributing in different areas of interest but performances of all NGOs are not same. The different enabling and impending factors play the role to insure the quality and performance of NGOs.

In the context of Nepal, geographically Nepal has covered three different geographic: Hill, mountain and Terai (plain area). Because of these distinct characters of Nepal, the accesses of services are different. NGOs have been working in all three geographical areas. The internal and external environment may affect the performance of NGO. Socio-cultural, geographical, managerial, policies and other technical factors may determine the effectiveness of NGO. So, considering the roles of different factors, the study was designed to identify the enabling and impending factors of the NGOs focusing on the NGOs of Karnali zone of Nepal. Karnali zone has covered the five mountain districts; Dolpa, Mugu, Humla, Jumla and Kalikot. These all five districts are geographically located in hilly mountain to from the development perspective; it is remained backward and marginalized districts. Human Development Index (HDI) is lowest from all zones and districts of Nepal.

\section{METHODOLOGY}

The study was based on the qualitative design. The phenomenological approach was adopted to collect the opinion of respondents regarding the enabling and impending factors of NGO. Purposively qualitative instruments were administered to generate the information. Basically, key informants interview, focus group discussion and observation were done for data collection. Instruments were self-reported semi-structured. In total of 45 interviewed(beneficiaries - 20, NGOs board - 5, NGOs staff - 5, Civil society representative - 5 and Government Official - 10) and 15 focus group discussions were conducted. Instruments were pre-tested to insure the validity and reliability of instruments. The study observed the physical setting and emotional responses of NGOs and communities to verify the data.Manual editing, transcribed and narrative analysis was done for qualitative data.

\section{RESULTS}

History of NGOs working in the Karnali zone shows that NGOs had been working in the different areas of social sectors after restoration of democracy in 1990s. The study had rigorous discussion to identify the enabling and impending factors of NGOs performance. The participants of study as well as from the observation of study found the following factors as enabling and impending factors of NGOs for the overall development and effective service delivery: 


\section{Enabling Factors}

\subsection{Will power of NGOs working in Karnali Zone}

The study had found a lot of problem regarding the proper management of NGOs activities because of lack of trained manpower, inadequate infrastructure facilities, no easy access to capital city. Though, locally initiated NGOs have strong will power and commitment to work in these areas for the better development and change of society. Because of their strong will power, NGOs have been working since long time and till the date, it was found sustained in study areas.

\subsection{Donor Interest and contribution in Karnali Zone}

Geographically, Karnai zone is one of the most isolated areas so the government and donors have given priority from the development perspective. As the fundamental rules of Nepal Government, donors are not allowed to work directly in the field with community. They are advised that their development activities have to be delivered through government or NGOs. Working through and with government have so much administrative process and working channels are so much lengthy, therefore donors and INGOs become the first choice of NGO's as a development partners. There are so many sectors to work in the community due to still minimum physical infrastructures, illiterate, poverty and huge possibilities to promote and people have positive response for welcoming to the NGOs and funding agencies to meet their immediate needs and future development. The study was found that Karnali is one of the priority and donor interested area of Nepal which supported to run the NGO's activities.

\subsection{Tourism promotion:}

Promotion of the tourism sector in Karnali has more possibilities for NGOs. Tourism promotional products are pilgrims and spiritual places, hot springs, cultural diversity, high Himalayan, largest and dippiest Lake of Nepal adding beauty for the possibilities of tourism. The study also found that Nepal government established Karnali Tourism Board to develop tourism in Karnali for sustainable holistic development. Special budget allocation could support to change the socio-economic transformation of the people through tourism

\subsection{Structural factors}

An active participation of the citizens in all level program implementation, team member and executive boards resulted better result of the NGOs. Further, depth and widening participation of the socially excluded groups i.e. Dalit, women, youth, ethnic and poor is hallmark in the development of the civil society institution. This has brought mutual respect, created trusted environment and non-discrimination with groups. The financial resources of the program to implement the program in the community and competent human resources needed to facilitate, strengthened the capacity of the groups, effective coordination and monitoring, supervision and produce the reports to share among key stakeholders for the replicate the programs and learned lessons from the project.

The government favorable policies, cooperation and support of the government agencies make significant difference to growth of NGOs and its efficient operation. Government proactive initiations and positive attitude may change the lifestyle of the community receive support from NGOs/INGOs and funding partners.

\subsection{Environmental factors}

The study found political stability, political cultured applied, politically cleaned and politically respecting culture for opposite ideological parties' direct effect the NGOs growth and effective result of the projects. The democratic practices in all level and every institution create the positive and respecting environment. Enabling environment to express the freedom and 
rights, supportive relations of the state-civil society and private sector and NGOs, supportive legal provisions of the nation, and socio-economic and cultural equipped and farsighted environment support NGOs development. Strengthening networks, alliances and forums of the civil societies enhanced the capacity of the institutions and explore the creative and innovative ideas and solidarity in social issues and development agendas. An application and use of information technologies in the institutions and program produce reliable results and save time and human resources. Creating team working culture and enjoyable learning environment in the institution make a lot difference of its image and its outcome. Introducing and practicing result based performance of the human resources make success and result oriented institution in the district.

Community believes that if the NGOs are working there, then it will be definitely completed the works and get the better result impression created in the society.

\subsection{Ethical factors}

Program and information sharing and its transparency create the positive and supportive environment. NGOs work is operated on the basis of non-profit and volunteer modality which demands supporting hands from all. This is only possible based on what NGOs speak and do in the practices. It also shows that how accountable towards the beneficiaries, government and funding partners. Openness and respecting working culture increase the trust among NGOs and supporting agencies and direct beneficiaries. Proper utilization of the resources and position gives message for institutional ability and honesty.

\subsection{Program based factors}

The study also found that one of the enabling factors of the NGOs is effective program to the target group. Program activities have to be developed identifying the real needs of the community. The project period must be long term where visible impact can be brought implementing programs effectively. To make program success, community has to realize the actual their needs. An operation of the various program focused to Karnali people should not be resource duplication programs. It should be operated according to public demand and program should be designed bottom up rather than top up approach. In addition, need to give priority for local price/rate to carry out the work.

An emphasized given to those activities which are most needy in the community like HIV and AIDS and Drug Abuse Control program, Children and women welfare program, community and rural development programs i.e. Tourism, awareness raising, capacity building, drinking water, irrigation, mule track, road, bridge, agriculture, forest development and other program, Drinking water and irrigation development, Development of transportation, educational development program, environment preservation, differently-able people program, health services program, moral development program, youth related issues and program, information/communication and human rights promotion and protection program. For the effectiveness of the programs joint sharing/review and reflection for learning, replicate good practices and better implementation in the other needy communities. Social inclusion of the gender, caste, geographical, women, children, youths and marginalized groups of the society, rural backward community class, disability, dalit, relief operations for women, programs are conducted.

\subsection{Policy factors}

The study found that friendly rule and regulation and implementation procedures of the government contribute NGOs to implement programs, institutional development and their growth development initiatives: There should be clear demarcations in the role and working 
approach with government and NGO. Government has to make a clear policy and legal provisions. In addition uniformity in the rule, regulation and policy would create better environment for NGOs. Policies of the government have to create the space for NGOs. Strong provision has to be made for implementation of the programs jointly with local government agencies. Development activities should be jointly carried out with the partnership between NGO and government.

Tax exemption on funding amount and development activities for NGOs provisioned in the central and local government. NGOs reaching to government un-reach areas to facilitate the development services in the difficult geographical area where government could not able to serve and allocate resources. Demonstrate best quality work and innovative ideas and approaches. Dignified working culture has to be established in the country to work as NGOs and consider development partners.

It is necessary to establish the rewarding and punishment policy by the government for the NGOs and civil society who are doing good and bad. Decentralization and bottom up approaches has to be emphasized and in depth discussion at community and local level. Create favorable environment for the establishment and expansion of NGOs work with the motto of many NGOs in Karnali could contribute more for the empowerment of citizens and facilitate the developments in the ground. Government and civil society have to develop positive thinking praising for good would be better since innocent people who are waiting for the light of development.

State policy and provision should be addressed the social inclusion of the gender, caste, geographical, women, children, and youths and marginalized groups of the society, rural backward community class, disability and Dalit for the justice and equitable benefits to all.

\subsection{Institutionalized democratic practices}

Inclusive democratic practices of the NGOs enable to elect the leaders of the NGOs. Democratic exercise creates the space to involve in NGOs who are excluded in the society. Institutional development, promote good governance, accountability, promotion and enhance the capacity of the members. This helps the optimum utilization of the resources.

The study was assumed that Nepal Government policies had played the significant role to create the enabling environment for NGOs to perform their works was accepted. Government had provision to register, operate and implement the NGOs and its activities in Karnali zone.

\section{Impending factors of NGOs \\ 2.1 Geographical factors}

The study areawas located in the mountainous areas so out of 5 study districts; still there is not smooth road access in five districts and only Kalikot and Jumla seasonable transport in muddy road. Because of the inadequate infrastructure facilities; NGOs had problem to deliver their program effectively.

These districts are located in remote and far from capital, geographical difficulties and no basic infrastructures, rural areas and scattered inhabitants and uneducated society; infrastructures materials are so costly due to transportation. The study areas are known as deprived areas from the development perspective because of lack of electricity and communication, lack of required source and lack of opportunities. Government service delivery is inadequate and irregular. 
The political instability is in the country since long which is hugely affected in the Karnali zone as well. Political difference and influence in every sectors and every time. Support and disturbances of the programs based on political attachment. Further, negative attitude and thinking encouraged by hidden and political interest which is most difficult and barrier for the effective program implementation in the communities by NGOs. Government is not supportive and positive towards NGOs as they raised the issues of transparency, accountability and effective service system in the district and community.

\subsection{Weak Planning and implementation of program}

Most of the NGOs programs were depended on donors and funding partners. It needs the assessment and bottom up planning along with communities' participation. But donors fund for the funding partners, outlined time and utilization time frame was limited. The dependent mentality had hugely affected the plan and budget utilization and effective program implementation as per plan. In addition, social dispute and vested interest of some of the community leaders heavily affected the programs and budget utilization. In addition, expensive life style of NGOs and its staff members had also played the role to affect the support mechanism and impression of the communities. In some cases, leakage of budget at development work, nepotism, favoritism and partiality also had affected the program implementation. Establishment of Patimukhi, NGO was also one of the biggest barriers in the program. It was very common that coordination among all key stakeholders is one of the challenging works for NGOs. The NGO's board members reported that one of the reasons of failure of effective implementation of program and expected result was government policies, process and administrative mechanism. From the beneficiaries' perspective, NGO's were failed to identify the real need of poorest of the poor communities and not effectively reached to the door of targeted people. From Society hasn't kept the people of backward class as a major leader which have leads to have unsatisfactory program.

\subsection{Dependency mentality}

In Karnali, most of the higher government and non-government higher official and head of the institutions send from out of the Karnali Zone. In general practices, it is found that who are transferred or posted in Karnali Zone, they think that it is political punishment for them and government has deprived them from the access in decision making authorities. Therefore, they are not regularly staying in the district and performance is not satisfactory. On the other hand, because of some financial, technical and administrative reasons, the local NGOs and civil societies are depended on the government authorities for the implementation of NGO's activities. All local NGOs are depending on financial and higher level technical expertise to INGOs, donors and government agencies. Similarly, communities are also more dependent on external support instead of initiating by themselves. Mostly, NGOs programs, plan and implementation strategies were driven by donors rather than community demand model.

\subsection{Lack of Trained human resources}

NGOs have major problem is retaining skilled human resources and lack of resources for trained human resources as well. Capacity building of the team members of the institutions is challenging tasks. NGOs received the fund for the effective implementation of the programs which most compulsion to use the experienced and knowledgeable human resources. New and latest technological skills and knowledge contribute further to implement the program effectively and achieve the result facilitating the development activities in the communities. Vibrant leadership is one of the major factors which play significant role to extend the programs and institutional development. Similarly, local human resources are most important to facilitate the 
development program in the communities and create ownership among local people and build the public trust. Honest, skillful, committed and positive staff members are assets of the institution. Establishing organizations without knowing the organizational values and objectives could not fulfill the NGOs expectation. Knowledge of the local languages helps to implement the program success in the communities. In upper part of the Dolpa, Mugu and Humla local languages are widely spoken and cannot understand clearly.

\subsection{Inadequate Coordination and support between the stakeholders}

Coordination among the key stakeholders is one of the major factors to implement the projects in the community. Most of the respondent emphasized during the interview was the coordination among NGOs, funding partners, government agencies and civil society's leaders and beneficiaries from planning to the implementation and reviewing the projects. Smooth coordination contributes to create the healthy environment and build the trust among key stakeholders and encourage for the meaningful participation. NGOs work is voluntarily initiations from the institutions where the artful support is needed from the every stakeholders and government support is compulsion to implement the program in the needy communities but if the understanding and perception is different for the same program then various seen and unseen barriers will come and ultimately NGOs cannot implement the program effectively and beneficiaries deprived from the support. Common understanding and unity of the beneficiaries and local people could play the vital role of project success, mutual trust and respect.

\subsection{Lack of Monitoring and Supervision from Government agencies}

As per the social act, District Administration Office (DAO) and District Development Committee (DDC) are prime responsible for the effective monitoring and supervision of the NGOs performance. In addition district line agencies are also responsible for the spectral programs. But in practice, government agencies and Social Welfare Council SWC) had no adequate monitoring, supervision and evaluating NGOs performance and effective implementation of the programs in the communities' level. NGOs and civil societies programs are not effective if there is no proper guidelines', supervision and provision for reward and punishment.

\subsection{Socio-economic problem}

There is higher poverty, illiteracy and unemployment in the Karnali Zone. Due to minimum physical infrastructure, the cost was found comparatively higher in every item. Big economic challenges in economic perspective due to lack of modernize agriculture and domestic cottage industries. The study also found that less interferes of the financial support agencies and low income and miserable life styles in the Karnili Zone. Educational level was lower comparing with other parts of Nepal. Huge migration and its trend were rapidly increasingly to find the economic opportunities. Still traditional socio-economic practices continued and deeply rooted. Socio-culture and political environment of Karnali zone had played the role as impeding factors to perform the works of NGOs. The Karnali zone is known as marginalized areas because of the various causes; geographically, road access, electricity, economic status and level of awareness ...etc. All these factors had not supported to hire the trained manpower for the effective implementation of program so sometimes it became the barriers of development

\section{DISCUSSIONS}

The finding of the study was discussed with the findings of various previous literatures. The previous literatures have also explored the different factors as the enabling and impending factors. The finding of this study is mostly found supported by the previous literatures also. The 
previous study reported that transparency of NGO is one enabling character which supports the effective performance of services. The social audit is one activities being carried out the various NGOs in Nepalese context also. So, social audit is taken as the enabling factors of the NGO. As the Gopal, K. S., "Social audit is a dynamic tool by which people are able to make officials account- able for their performance in the delivery of legally enshrined rights $(2009, \mathrm{p}$. 70$)$. One of the most positive developments emerging from the social audits is the creation of new partnerships between the government and civil society organizations, benefiting all parties. The latter participate in the conduct of social audits on a voluntary basis. Officials at the state and district levels take the responsibility for ensuring access to official records, training in social audits, and commit to taking corrective action on the issues arising out of the audits. Together, the government and civil society participants all have the opportunity to see their efforts create real, positive changes for the people they serve (Kidambi, 2007, p. 345). NGOs can solve the specific problems of the local areas and are often quicker than the government bureaucracy. In communications, NGOs are fast and efficient. They translate the concern of the people and provide the services to the local communities with the involvement of locals (Bhandari, 2014, p. 184).

Both national and international policy-making institutions have acknowledged the contribution of NGOs in alleviating poverty, through empowering the poor and continuing to support their endeavorsInvalid source specified.. In Nepal, transformation is taking place in every sector such as in political sector, economic sector, social sector, and cultural sector. NGOs and CBOs are key stakeholders to bring change in Nepal (Bhandari, 2014, p. 186). The study also reported that basically rights based NGOs played the significant role to promote the knowledge of demographic practices to general public which also finally supported to the establishment of the demographic practices in Nepal.

Nongovernmental organizations seem to represent the best of private citizens responding to global inequities. But behind the characteristics inherent to an NGO model of development are lurking several challenges: too many actors, too many chiefs, and too much mission From the perspective of NGOs, the heart of the problem is the shortfall in organizational capacity, the seriousness of which compounded by many NGOs, having to face the problem of high staff turnover as skilled staff move into government and state-run institutions (Taylor, 1999, p. 79). Coordination between NGOs and governmental authorities is still based on personal relations. Despite some of these weaknesses of governance of Nepali NGOs they are growing and able to create their institutional space (Dhakal, 2007, p. 72).

Many NGOs have found it difficult to access government support, set up partnerships, and obtain funding (Taylor, 1999, p. 78). It is obvious that some NGOs are doing well, and others manage their activities in a terribly poor manner. This disparity can be taken as one of the challenges of NGO governance in Nepal (Dhakal, 2007, p. 72). The main danger of the NGOs are to meet the internal organizational objectives, such as job security, increasing employment opportunities, and overtaking competitor NGOs, displace development objectives (Hulme, 1992, p. 80). These, in turn, are seen as essential steps on the way to achieving good governance and, ultimately, poverty reduction. First, this approach is driven by the sea change in the development cooperation that rests on the three pillars of the U.N.'s Millennium Development Goals (MDGs) of 2000, the Paris Declaration on Aid Effectiveness (2005), and the Accra Agenda for Action (2008); the change has shifted the focus from infrastructure development to the improvement of key social factors and governance as the most crucial contribution to poverty alleviation (Dosch, 2012, p. 1074).However, it is yet to prove their institutional significance for consciousness for 
creating "civil society" not only self-satisfaction. It is obvious that some NGOs are doing well, and others manage their activities in a terribly poor manner. This disparity can be taken as one of the challenges of NGO governance in Nepal (Dhakal, 2007, p. 72). The study also found that socio-culture and political environment, lack of effective monitoring, dependency mentality are some major impeding factors which affect the performance of NGOs.

\section{CONCLUSION}

The study found that the major enabling factors were will power of NGOs working in Karnali Zone, donor Interest and contribution in Karnali Zone, Structural factors, Environmental factors, Ethical factors, Program based factors, Policy factors and Institutionalized democratic practices. Similarly, impending factors were environmental factors, weak planning and implementation of program, dependency mentality, lack of trained human resources, inadequate coordination and support between the stakeholders, lack of monitoring and supervision from government agencies, socio-economic problem. It is to recommend that Government should develop the effective policy to address the impending environment which can create supportive environment to NGO to work independently and effectively.

\section{BIBLIOGRAPHY}

Bhandari, M. (2014). Civil Society and Non-Governmental Organizations (NGOs) Movements in Nepal in terms of Social Transformation. Pacific Journal of Science and Technology, 177-189.

Dhakal, T. N. (2007). Challenges of Civil Society Governance in Nepal. JOAAG Vol. 2 no 1, 6566.

Dosch, J. (2012). The Role of Civil Society in Cambodia's Peace-building Process: Have Foreign Donors Made a Difference? Asian Survey, 52(6), 1067-1088.

Fowler, A. (1991). Building Partnerships between Northern and Southern Development NGOs: Issues for the1990s. Development in Practice, 1(1), 5-18.

Gopal, K. S. (2009, January). NREGA Social Audit: Myths and Reality. Economic and Political Weekly, 44(3), 70-71.

Hulme, M. E. (1992, June). Scaling up NGO Impact on Development: Learning from Experience. Development in Practice, 2(2), 77-91.

Kidambi, K. V. (2007, February). Challenging Corruption with Social Audits. Economic and Political Weekly, 42(5), 345-347.

Lenihan, E. W. (2006, August). Accountability and Effectiveness of NGOs: Adapting Business Tools Successfully. Development in Practice, 16(5), 412-424.

Smillie, I. (1994, June). Changing partners: Northern NGOs, Northern governments. Voluntas: International Journal of Voluntary and Nonprofit Organizations, 5(2), 155-192.

Taylor, A. H. (1999, March). South Africa: Anti-Apartheid NGOs in Transition. Voluntas: International Journal of Voluntary and Nonprofit Organizations, 10(1), 73-82. 